\title{
IMPROVING WORKING AGE YOUTH ENTREPRENEURS SKILLS WITH PRODUCT QUALITY IMPROVEMENT TRAINING AND CUPPING COFFEE TESTS TO FACE NEW NORMAL CHALLENGES IN NORTH ACEH
}

\author{
Hafni Zahara ${ }^{1}$, Fadli $^{2}$, Emmia Tambarta $^{3}$, Irada Sinta ${ }^{4}$ \\ ${ }^{1,2,3,4}$ Faculty of Agriculture Universitas Malikussaleh \\ Corresponding Author: irada@unimal.ac.id
}

\begin{abstract}
The increasingly massive Corona Virus Disease (COVID-19) pandemic has recently changed the system/order of people's lives in Indonesia. This system is known as the New Normal Era. At this time, the existing employment system in Indonesia forced various job providers to reduce the number of workers due to capital problems and social distancing rules. The prohibition of gathering in one place en masse caused job providers to lay off some employees, thus increasing the number of unemployed. This also happened in North Aceh District. Many young workers are forced to leave work because of the limited job opportunities available in North Aceh District. The formation of a new business/business accompanied by the skill of understanding the quality of the product to be produced is the best solution in this condition. Understanding product quality will certainly help entrepreneurs to determine market segmentation, marketing strategies, production costs, types of raw materials used and what risks must be faced. One of the businesses that are very popular with entrepreneurs today is the business of processed drinks from Arabica coffee commodities. Arabica coffee from Aceh Province is better known as Gayo coffee. Gayo coffee is quite famous in the world because it has a distinctive aroma and enjoyment and if it is cupped or taste tested. The location of community service is taken in the North Aceh Regency area considering the location of the Faculty of Agriculture, Malikussaleh University which is located in North Aceh Regency, it is expected to be able to make a direct contribution to reducing unemployment through deepening entrepreneurial skills in working age youth through product quality improvement training and coffee test cupping to face new normal challenge in north aceh. The implementation method is designed for mentoring in the form of a participatory approach and refers to the adult learning process (adult-learning) which consists of: (1) Presentation of material equipped with Power Point presentations and simulation materials, (2) limited discussion in accordance with health protocols to prevent the spread of COVID, (3) the assignment or practice of physical testing and coffee cupping tests are (1) to produce agents of change in the "job creation" paradigm from the "job seeker" paradigm among working-age youth, (2) become a forum for soft skills training related to product quality for youth of working age as a provision for business/business formation activities, (3) as a reference for the next community service activity. The output targets to be achieved from this activity are:Publication of activities in print or online media, (3) Survey/Questionnaire of Understanding Product Quality Control to assess the improvement of Human Resources competitiveness.
\end{abstract}

Keywords : Cupping Test, Gayo Arabica Coffee, Product Quality, Working Age Youth, Entrepreneurship.

\section{INTRODUCTION}

The increasingly massive Corona Virus Disease (COVID-19) pandemic has recently changed the system/order of people's lives in Indonesia (Fadli, 2020). This system is known as the new normal era. At this time, the existing employment system in Indonesia forced various job providers to reduce the number of workers due to capital problems and social distancing rules. The prohibition of gathering in one place en masse caused job providers to lay off some employees, 
thus increasing the number of unemployed. This also happened in North Aceh District. Many young workers are forced to leave work because of the limited job opportunities available in North Aceh District. The lack of opportunities for civil servant recruitment formations for North Aceh Regency is also one of the causes of the large number of unemployed in this area. This problem is the main reason for Malikussaleh University to be able to give birth to agents of change who have a job/business creation paradigm. The expected change agents from this activity are people who are of working age and have a high entrepreneurial spirit. So that later the paradigm of "job seekers" can shift to "job creators".

Entrepreneurship is one of the professions that is often proud of, because it is felt that it can improve the standard of living and especially if it can create jobs for others. In the life of the wider community there is a view that entrepreneurs are born based on heredity. Through research conducted by Akola and Heinonen in 2006 (cited in Valerio, A. et.al, 2014) it was shown that there are aspects of entrepreneurship that can be taught, namely business and management skills and there are aspects of entrepreneurship that cannot be taught, namely creativity. and innovative thinking except through practical experience. From research conducted by Akola and Heinonen (2006) in Valerio,

The formation of a new business/business must of course be accompanied by skills in understanding the quality of the product to be produced. Understanding product quality will certainly help entrepreneurs to determine market segmentation, marketing strategies, production costs, types of raw materials used and what risks must be faced. One of the businesses that are very popular with entrepreneurs today is the business of processed drinks from Arabica coffee commodities. Arabica coffee from Aceh Province is better known as Gayo coffee. Gayo coffee is quite famous in the world because it has a distinctive aroma and enjoyment and if it is cupped or taste tested. Research by Tambarta (2016) states that despite the crisis in Europe, does not reduce the demand for coffee from the highlands Gayo Landin the world market. The opportunities that exist to grow the coffee product business/business include, among others, various aspects such as the strategic environment, demand, resources, technology and product quality. The business development applied is sustainable business development that does not only focus on quantity but also on quality and customer satisfaction so that an understanding of product quality is very important to pay attention to.

Processed coffee beverage products are also very concerned about the quality of the raw materials. Processed raw materials for coffee drinks with good quality will also produce coffee drink products with excellent taste. Therefore, prospective entrepreneurs must be able to understand in depth the skills of improving the quality of coffee products. Malikussaleh University through PNBP funding has a concentration on studying, developing, applying and providing information/science related to coffee commodities from the upstream subsystem (production and cultivation facilities) to the downstream subsystem (post-harvest processing, quality assurance, marketing and support). This concentration is contained in the master plan for research and service that has been established by Malikussaleh University. Through this community service program,

\section{IMPLEMENTATION METHOD}

\subsection{Devotion Location}

The location of community service is taken in the North Aceh Regency area considering the location of the Faculty of Agriculture, Malikussaleh University which is located in North Aceh Regency, it is expected to be able to make a direct contribution to reducing unemployment through increasing entrepreneurial skills in working age youth through product quality improvement training and coffee cupping tests to face new normal challenge in north aceh. 


\subsection{Implementation Stage}

The implementation stages are designed for mentoring in the form of a participatory approach and refer to the adult learning process (adult-learning), which consists of: (1) Presentation of material equipped with Power Point presentations and simulation materials, (2) limited discussion in accordance with health protocols to prevent the spread of COVID, (3) the assignment or practice of physical testing and coffee cupping tests as shown in the following picture:

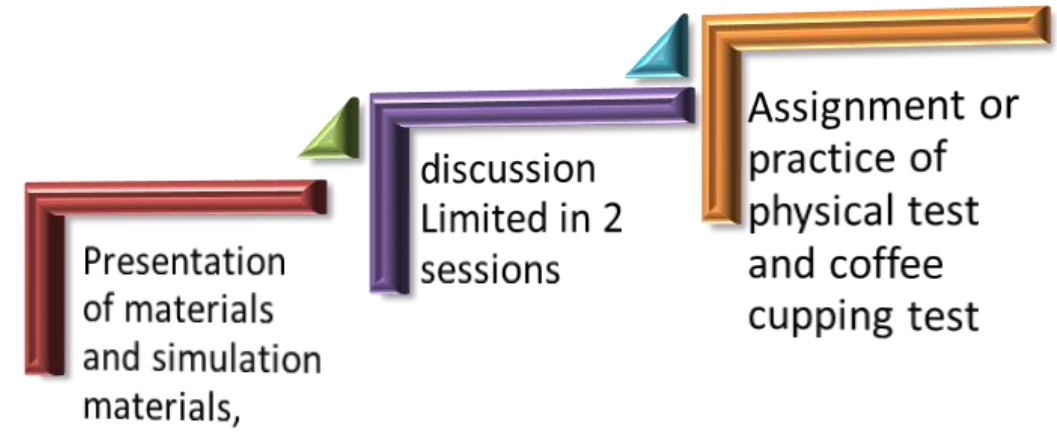

Figure 1. Flow of Community Service Activities

At the initial stage it will bepresentation of material equipped with a Power Point presentation to discuss the general standard of testing on coffee beans in Indonesia which is carried out in two ways, namely physical testing and organoleptic testing (cupping test). Physical testing is a system used to assess the quality of coffee beans based on their physical properties, either using assistive devices or using human senses in accordance with applicable standards. There are two standards that serve as guidelines for the physical test, namely the Indonesian National Standard (SNI) and the Specialty Coffee Association of America (SCAA) Standard. Standards for specialty coffee consist of: (1) The maximum number of defects is 5 and free from primary defects, (2) there is no Quicker in roasting beans, (3) a minimum cupping score of 80 , (4) the uniformity of beans reaches $95 \%$. Standard premium coffee beans are:

In the second stage, namely Limited discussions will be conducted in accordance with health protocols to prevent the spread of COVID. In the discussion phase, trainees will be given the opportunity to ask questions in two sessions. Furthermore, in the third stage, namely the assignment or direct practice related to coffee quality control, it will be carried out in two ways, namely physical tests and organoleptic tests. The stages of physical testing carried out on coffee beans consist of:

\section{a. Test Defect}

Decect is the sum of the defects in coffee beans. This test is usually carried out on ready-to-export and specialty beans. The SOPs used are SNI and SCAA. According to the SNI system, grade 1 coffee beans only have a maximum defect value of 11. Meanwhile according to SCAA are: (1) For grade 1 (premium): the maximum number of defects is 8 , there may be major defects, the maximum roasted beans show 3 defects, (2) For specialty: the maximum number of defects is 5 , free from major defects, no quacker is seen in roasted.

Defective seeds are divided into primary and secondary defects. Primary defective seeds consist of: black seeds, cocoa beans, logs, moldy seeds, many hollow seeds, materials other than coffee (stone, wood, twigs, and others). The secondary defects consist of partially black seeds, partially brown seeds, grain, white seeds, young seeds, wrinkled seeds, single hollow seeds, cracked seeds, and coffee husks (Hull).

\section{b. Seed Size Test}

This test is carried out to determine the size of coffee beans, namely large bean size (L), medium bean (M), small bean (S). This test is carried out using a screen consisting of several 4 minimum levels. These levels have hole sizes of 18 inches, 16 inches, 14 inches, and 13 inches. 
Improving Working Age Youth Entrepreneurs Skills With Product Quality Improvement Training and Cupping Coffee Tests to Face New Normal Challenges in North Aceh

DOI: 10.54443/irpitage.v2i1.62

Good coffee beans are those that have uniform size according to their respective sizes. This is to ensure the beans ripen evenly during the roasting process. Organoleptic tests will be carried out by cupping tests. In the Cupping Stages the test will be assessed:

\section{a. Color/Odor Test}

This test is carried out using the senses in the form of foresight in seeing and smelling. Good coffee beans have a fresh smell and bright color and are not contaminated with foreign substances that cause discoloration and odor.

\section{b. Gayo coffee taste}

Coffee taste can be tested by organoleptic test (cupping test). This test is one of the quality assessment systems for commodities that use human senses such as hands, tongue, ears, and eyes as measuring instruments. The person who performs the organoleptic test is referred to as a panelist. Panelists are tasked with measuring and assessing the characteristics of coffee such as acidity, clarity of taste, fragrance and so on. This test is very popular with coffee producers and marketers because it is able to provide clarity about the unique taste characteristics of the various types of coffee available. In this case, the panelist acts as a measuring tool. A good panelist is a sensitive and consistent panelist. Panelists' sensitivity includes the sensitivity to recognize, differentiate, and compare the characteristics of certain coffees. After testing the coffee, the cupping form will produce a certain score for the various types of coffee being tested. A score range of 6-7.75 indicates that the coffee is of fairly good quality, while a score exceeding 8.00 is said to be specialty coffee.

\subsection{Activity Evaluation and Impact Instruments}

The instrument for evaluating the results of service activities used was in the form of a questionnaire with open-ended questions regarding the understanding of the training participants about the materials and practices presented in this training. The expected impact of service activities are:

1. There is a paradigm shift from "job seekers" to "job creators"

2. The spread of information related to the things that must be done for entrepreneurship in the coffee sector

3. Working age youth are able to understand coffee quality knowledge such as sorting, cupping test, coffee roasting methods, etc., to working age youth in order to create a coffee business that has a stable taste,

4. The emergence of entrepreneurs who have the skills to understand product quality in the coffee business through sorting training and coffee cupping tests.

\section{RESULTS AND DISCUSSION}

This service activity is carried out in the North Aceh Regency area considering the location of the Faculty of Agriculture, Malikussaleh University, which is located in North Aceh Regency, it is expected to be able to make a direct contribution to reducing unemployment through increasing entrepreneurial skills in working age youth through product quality improvement training and coffee cupping tests to face new normal challenge in north aceh. The training participants are young people of working age who do not have a business during the covid pandemic or are affected by the pandemic because they cannot find work outside the area due to lockdown or social distancing regulations. In this training, young people of working age are taught organoleptic test techniques to see the quality of the Gayo Arabica coffee that has been provided.

Organoleptic test is a quality assessment system for commodities that uses human senses as measuring instruments such as hands, tongue, nose, ears and eyes. The person who performs the organoliptic test (Panelist/cupper) will measure and assess the taste that cannot be measured with equipment. In organoleptic testing, panelists act as measuring instruments. A reliable panelist is a panelist who is sensitive and at the same time consistent, Panelist sensitivity includes sensitivity to recognize, sensitivity to distinguish \& compare. The training began with an opening by the MC by 
the Alumni of Agriculture, Ade Yustika, SP. The event was officially opened by the head of the community service team, Mrs. Hafni, Zahara, SP, M.Si.

The next event was the provision of material by the presenters of the Organoleptic Test / cupping test, namely Mrs. Emmia Tambarta, SP, M.Sc. The training was divided into two sessions, namely a session on recognizing the quality of Gayo Arabica coffee beans based on the five senses of the eyes and nose directly. This is done by comparing the color uniformity of the coffee beans purchased. If the color of the coffee beans is uniform, then the coffee beans can be said to have good quality. The second stage is the Organoleptic Test process, namely the introduction of the quality of Gayo Arabica coffee by using the five senses of smell (nose) and taste (tongue). This test is better known as the cupping test. This test process begins with grinding Gayo Arabica coffee beans that have been weighed with a coffee grinder.

The ground coffee that has been grinded is then placed in a glass cup for a cupping test with the following criteria:

1. Roasting coffee at Medium Roast level : Agtron \#58-63

2. Roasting Time: $8-12$ minutes

3. After roasting coffee stored: 8-24 hours

4. Griwall before cupping : $<15$ mins

5. UKGrind size: $70-75 \%$ pass or 20 mesh sieve

6. Ratoi powder and water : $8.25 \mathrm{Gr} / 150 \mathrm{Ml}$ of water, according to the size of the glass

7. KWater concentration : $125-175 \mathrm{ppm}$

8. Twater temperature : $92-96 \mathrm{C}$

9. Extraction Time : 4 minutes

10. JMin number of glasses: 5 uniform glasses

The cupping test begins with the aroma test. The aroma test is a test that uses the sense of smell. This test is carried out by preparing coffee brewed with the following criteria. Aroma process is done by bringing the nose closer to the cupping glass while stirring the surface of the coffee solution to get the aroma/break. Next Clean the foam on the surface of the solution using two spoons to proceed to the taste test process with the sense of taste (tongue). After the temperature reaches $70^{\circ} \mathrm{C}-73 \mathrm{C}$ the coffee is ready to be analyzed/assessed by sipping. Coffee began to be given an overall rating including fragrace/aroma, flavour, aftertaste, acidity, body, balance, uniformity, sweetness, clean cup, overall and defects, if any.

The assessment attributes in Cupping assessed by the training participants are as follows:

1. Fragrance/Aroma

- Fragranceis the smell of freshly ground coffee while it is still dry (called dry fragrance)

- Aroma is the smell of coffee when infused with hot water and steam is released (called WET aroma)

- Examples of some scent descriptions are: Floral, jasmine, tea rose, fruity, berry, spicy, woody, nutty, sweet, smoky, ashy, burnt, etc.

2. Flavor

Flavoris a combination that is felt on the tongue and the aroma of steam on the nose that flows from mouth to nose. The value assigned to flavormust include the effect, quality and complexity of the combined taste and aroma when the coffee is taken into the mouth so strongly that it involves the entire palate in assessing, flavorcan change according to temperature.

3. After taste

After Taste is defined as the length of positive taste quality that originates at the back of the palate and remains after the coffee is swallowed.

4. Acidity 
Acidityoften described as a distinctly sour taste, or sour if unpalatable. Good acidity describes good coffee, sweet and like the taste of fresh fruit that is immediately felt when the coffee is sipped. Acidityywhich is too dominant is categorized as unpleasant, acidity can change according totempratures!

Some example descriptions acidityis : citrus, lemonade, lime, orange, tangarine, mandarin, grapefruit, winey, sour, vinegar, malic, peach, pineapple, mango, apricot, tomato, strawberry

5. Body

Body is a touch feeling heavy/thick or light liquid in the mouth, especially felt between the tongue and the roof of the mouth, it results from dissolved solids and oils suspended in the liquid. Assessment example body in the mouth are: watery, oily, buttery, creamy, silky, smooth, astringent, chalky, dry

6. Swetness

Sweetness The presence of a pleasant sweet taste because coffee contains carbohydrates. The opposite of sweet in this context is sour, astringent or raw.Sweetnessthis is unlike the taste of sucrose found in soft drinks. A score of 2 is given to each bowl and the total score is 10 for 5 bowls. Examples of sweet descriptions in coffee likeHoney, Hazelnut, Caramel, Toffee, corn, cane sugar, chocolate

7. Uniformity

The existence of uniformity of aroma and taste) of each bowl. If the aroma of a bowl is different, then the score for this criterion is low, a score of 2 is given to each different bowl and the total score for 5 bowls is 10

8. Clean Cup

Meshows the absence of negative values from the beginning in the form of taste to aftertaste. In assessing this criterion, it is necessary to pay attention to from the beginning in the form of taste until the coffee liquid is swallowed or vomited. A score of 2 is assigned to each negative bowl and the total score for the 5 bowls is 10 .

9. Balance

Balance isbalance All aspects flavor, aftertaste, acidity, body.JIf one aspect is less or more than in the example, it results in a valuebalancewill decrease, in other words balance is the absence of a dominant taste or aroma.

10. Deffect

Deffectis a negative aroma and taste or defect in coffee that can reduce the quality of the assessment of coffee. There are 2 types of defects, namely:

- Taint, value of defect 2: if the defect in fragrance / aroma or taste but not excessive, for example:

$$
\begin{array}{ll}
\text { Slight moldy } & 2 \text { defects } \\
\text { Slight earthy } & 2 \text { defects } \\
\text { Slight Acidic } & 2 \text { defects }
\end{array}
$$

- Fault, is worth a defect 4: if the defect in the fragrance / aroma or taste is real and clear and even extraordinary, for example:

Seriously moldy 4 defects

Seriously earthy 4 defects

Seriously Acidic 4 defects 


\section{धीRITAGE}

This training was closed with a photo session with the service team with the training participants.

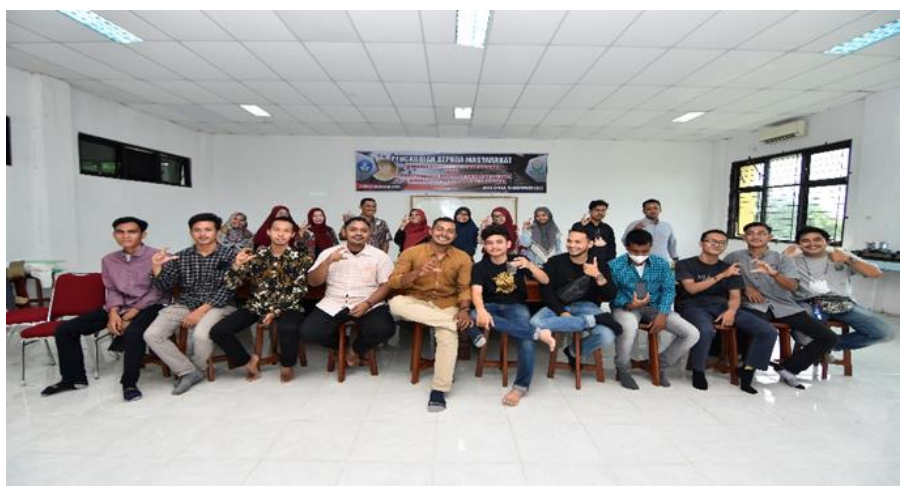

Figure 2. Group photo with trainees

\section{CONCLUSION}

This service activity is carried out in the North Aceh Regency area considering the location of the Faculty of Agriculture, Malikussaleh University, which is located in North Aceh Regency, it is expected to be able to make a direct contribution to reducing unemployment through increasing entrepreneurial skills in working age youth through product quality improvement training and coffee cupping tests to face new normal challenge in north aceh. The training participants are young people of working age who do not have a business during the covid pandemic or are affected by the pandemic because they cannot find work outside the area due to lockdown or social distancing regulations. In this training, young people of working age are taught organoleptic test techniques to see the quality of the Gayo Arabica coffee that has been provided.

The training was divided into two sessions, namely a session on recognizing the quality of Gayo Arabica coffee beans based on the five senses of the eyes and nose directly. This is done by comparing the color uniformity of the coffee beans purchased. If the color of the coffee beans is uniform, then the coffee beans can be said to have good quality. Gayo Arabica coffee beans that have a uniform color mean that they are harvested simultaneously (there are no white/underripe beans and rotten/ripened beans included in the harvesting process). Next Clean the foam on the surface of the solution using two spoons to proceed to the taste test process with the sense of taste (tongue). After the temperature reaches $70^{\circ} \mathrm{C}-73 \mathrm{C}$ the coffee is ready to be analyzed/assessed by sipping. Coffee began to be given an overall value including fragrace/aroma, flavour, aftertaste, acidity, body.

\section{Acnowledgment:}

Thank's a lot to Radja Publika as the head officer of IRPITAGE Journal who has facilitated the process of publishing this scientific article and also especially to LPPM Universitas Malikussaleh. who is willing to cooperate in the process of publishing articles about Improving Working Age Youth Entrepreneurs Skills With Product Quality Improvement Training and Cupping Coffee Tests to Face New Normal Challenges in North Aceh.

\section{REFERENCES}

Fadli, Suryadi, Tambarta, E., 2020. Arabica Coffee Marketing Constraints During the Covid 19 Pandemic In Central Aceh. J. farm business 6, 115-122.

Karim, Abubakar. 2012. Local Economy Through the Revitalization of People's Coffee Farms in the Gayo Highlands. J Economics of Development Vol (3). 
Improving Working Age Youth Entrepreneurs Skills With Product Quality Improvement Training and Cupping Coffee Tests to Face New Normal Challenges in North Aceh

DOI: 10.54443/irpitage.v2i1.62

Tambarta, Emmia. 2016. Analysis of Added-Value And Strategic Development of Gayo Coffee Products in Bener Meriah Aceh. IJSR Vol (5).

Valerio, A., Parton, B. \& Robb, A. 2014. Entrepreneurship education and training programs around the world: Dimensions for success. Washington, DC : The World Bank 